\title{
LOWER CARBONIFEROUS FOSSILS IN THE COAL-MEASURES.*
}

Mr. R. W. Skipsey has asked by letter if Mr. J. Ward (a note from whom appeared in the last No. of the Georogrcal Magazine, p. 234) will be good enough to state if the English discoveries made by himself and the Geological Surveyors have been published; and, if so, where and when. He asks also for the description of the fossils found, the character of their holding-ground, and that of the immediately adjacent strata, as well as the relative position and distance which such ground holds to the Millstone-grit, well enough known to hold some Carboniferous Limestone forms.

Mr. JoHN WARD, writing May 9th, states-' You will find a notice of the discovery of the marine fosils, by Messrs. Hull and Green, in the "Trans. Manchester Geological Society," vol. iii. No. 15, Session 1861-62, p. 348. The fossils are also figured and described by Mr. Salter in Mr. Hull's "Memoir of the Country around Oldham" (Geological Survey Memoirs).

'The fossils I found (Mr. Ward adds) in the Upper Middle Measures at Longton were determined by Mr. Salter as Lingula (two species), Discites falcalus, Discina nitida, Macrocheilus, Aviculopecten, Ctenodonta, and others. The bed I found them in will be passed through again in a few months, when $I$ hope to add many more species to the list.'

To the Editor of the Geological Magazine.

Sir,-In the newspapers it is stated that a cottage has been seen to sink wholly into the earth near 'Tredegar, South Wales, by the - collapse of some old coal-mine, certainly, it is stated, 100 feet below. As this seems to offer some support to Mr. Fisher's hypothesis (Grological Magazine, Vol. II., No. III., p. 102) for the formation of the Lexden Pit, by the giving way of the Chalk at about 142 feet below the surface, I think it worth notice.-ENQUIRER.

MISOEIIAINEOUS-

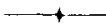

OBITUARY NOTICE OF HENRY CHRISTY, F.L.S., F.G.S., \&c. \&c.

Henry Christy, born July 26, 1810, was the son of William Miller Christy, the inventor of the Penny Receipt-stamp; was a partuer in the eminent house of Christy and Co. in Gracechurch Street, and succeeded his father as a Director of the London JointStock Bank. He displayed in commercial matters the same indomitable energy which he afterwards devoted to scientific pursuits. In 1850 he travelled to the East. His turn of mind was then strongly Ethnological, as exhibited by his collection of primitive Eastern fabrics. He also brought from Cyprus an extensive collection of

* Perhaps some of our readers may hare to be reminded that in England the real Coal-measures (those above the Nillstone-grit) are divided into Upper, Niddle, and Lower; whilst in Scotland the coal-beds associated with the Yoredale Series and Mountain-limestone are termed the Lower Coal-measures; and the Coal-measures proper are leferred to as the $\mathbf{U}$ pper Coal-measures.--Eviron. 